\title{
PENDEKATAN MULTI REZIM HUKUM ( MULTI DOOR SYSTEM) PADA TINDAK PIDANA PERIKANAN
}

\author{
Hamzah Kharisma \\ Syafruddin \\ Kementrian Kelautan dan Perikanan \\ kharismah@yahoo.com
}

\begin{abstract}
ABSTRAK
Kejahatan perikanan yang terjadi di dunia, khususnya Indonesia, dewasa ini tidak lagi terbatas pada masalah administrasi saja, Banyak tindak pidana lain yang juga terjadi bersamaan terjadi dalam tindak pidana perikanan. Perbuatan pidana di atas masing-masing mempunyai konsekuensi tersendiri yang tidak sama, ada kalanya suatu tindakan pidana yang ternyata diatur dalam lebih dari satu ketentuan pidana. Tindak pidana perikanan sebagai pidana asal (predicate crime) sering kali tidak maksimal dalam penanganannya dikarenakan kewenangan penyidik perikanan sesuai Undang undang No. 45 tahun 2009 sebagimana telah diubah dan ditambah dengan Undang undang No. 31 tahun 2004 tentang Perikanan yang terbatas mengakibatkan tidak terprosesnya tindak pidana lain. Tindak pidana perikanan sebagai kejahatan ekonomi dan lingkungan yang merupakan kejahatan yang luar biasa (extraordinary crime) sehingga harus ditangani dengan cara luar biasa (extraordinary act). Hasil penelitian ini menunjukan bahwa pendekatan multi-rezim hukum (multi door approach) terhadap tindak pidana perikanan dan tindak pidana lain terkait perikanan dapat dilakukan dengan penerapan concursus realis.
\end{abstract}

Kata Kunci : Tindak Pidana Perikanan, Multi-rezim hukum, dan Concursus realis.

\begin{abstract}
Fisheries crimes that occur in the world, especially Indonesia, today are no longer limited to administrative problems. Many other crimes that occur simultaneously occur in criminal acts of fisheries. The criminal acts above each have their own unequal consequences, there are times when a criminal act turns out to be regulated in more than one criminal provision. Fisheries criminal acts as predicate crime are often not optimal in handling due to the authority of fisheries investigators in accordance with Law No. 45 of 2009 as already amended and supplemented by Law No. 31 of 2004 concerning limited fisheries resulted in the non-processing of other criminal acts. Crime of fisheries as an economic and environmental crime which is an extraordinary crime (extraordinary crime) so it must be handled in an extraordinary way (extraordinary act). The results of this study indicate that a multiregime approach to law (multi-door approach) to criminal acts of fisheries and other criminal acts related to fisheries can be done by applying Concursus realist.
\end{abstract}

Keywords: Fisheries Crime, Multi-regime law, and Concursus Realist 


\section{PENDAHULUAN}

Indonesia sering disebut negara bahari, hal ini dikarenakan sebagian besar wilayahnya terdiri dari laut. Menurut catatan WALHI Indonesia adalah negara kepulauan terbesar di dunia, yang memiliki 17.480 pulau dengan garis pantai sepanjang 95.181 km. Berdasarkan Konvensi Hukum Laut (UNCLOS) 1982, Indonesia memiliki kedaulatan atas wilayah perairan seluas 3,2 juta $\mathrm{km}^{2}$ yang terdiri atas perairan kepulauan seluas 9,2 juta $\mathrm{km}^{2}$ dan laut teritorial seluas 0,3 juta $\mathrm{km}^{2}$.

Secara ekonomi, hasil sumber daya kelautan telah memberikan kontribusi terhadap pembentukan PDB nasional sebesar 22\% pada tahun 2014. Padahal wilayah Indonesia mencapai $5.193 .253 \mathrm{~km}^{2}$, yang terdiri atas $1.890 .754 \mathrm{~km}^{2}$ daratan dan $3.302 .498 \mathrm{~km}^{2}$ adalah lautan (Seminar Indonesia 2014-2019, Poros Maritim untuk Kesejahteraan dan Keadilan, Rokhmin Dahuri, Menara Batavia, Kamis 14 Agustus 2014). Secara biofisik, wilayah pesisir Indonesia merupakan pusat biodiversity laut tropis dunia karena hampir 30\% hutan bakau dan terumbu karang dunia terdapat di Indonesua. Namun, kekayaan pesisir dan keluatan yang kita miliki, terdapat lebih dari 5.254.400 orang di wilayah pesisir hidup dalam kondisi sangat miskin. ${ }^{1}$

Sejak awal dikumandangkan Deklarasi Djoeanda (1957) telah memberikan keteguhan atas konsepsi Indonesia sebagai negara kelautan yang besar, berdaulat dan sejahtera. Laut tidak hanya dilihat sebagai media juang negara, tetapi turut sebagai ruang pengidupan rakyat Indonesia. Namun, kondisi hingga hari ini tidak memberikan sesuatu yang cukup berarti bagi mereka yang menggantungkan hidupnya pada pengelolaan sumber daya pesisir dan laut Indonesia, seperti nelayan dan petambak tradisional, menjadi komunitas masyarakat yang rapuh secara ekonomis, pendidikan, kesehatan, dan hal-hal mendasar lainnya.

Kondisi di atas menunjukkan kurang maksimalnya pemanfaatan sumber daya laut yang diperparah dengan lemahnya sistem keamanan laut. Maraknya kasus pencurian ikan oleh kapal-kapal besar dengan peralatan yang lebih canggih menunjukkan bahwa pengawasan dan perlindungan terhadap wilayah perairan Indonesia kurang diperhatikan. Kasus-kasus ini sering terjadi tanpa adanya upaya yang serius dari pemerintah untuk mengungkapnya. Lemahnya pengawasan dan penegakkan hukum terhadap para pelaku illegal fishing ini telah menyebabkan para pelakunya tidak pernah jera. Proses hukum yang ada selama ini hanya menyentuh kalangan awak kapal semata tanpa berusaha mengungkap otak pelaku yang sesungguhnya, yaitu corporate

${ }^{1}$ Potret Advokasi Ekologis Vis a Vis Kejahatan Korporasi, 25 Juni 2009, http://www.walhi.or.id. Diakses pada tanggal 27 September 2018. 
yang membackingi kegiatan tersebut. Hal ini yang menyebabkan kerugian besar terhadap negara, kalangan nelayan tradisional, dan masyarakat pesisir.

Bahkan, pemerintahan Joko Widodo membuat kebijakan menenggelamkan kapal pelaku illegal fishing, hal ini masih menimbulkan 'kontroversi', apakah kebijakan ini akan efektif memberantas illegal fishing di Indonesia. Hal yang perlu dicatat, apakah kebijakan ini sudah menyentuh korporasi sebagai pelaku kejahatan yang sesungguhnya. Lemahnya koordinasi antar Instansi penegak hukum dapat menimbulkan tumpang tindih kewenangan dan kebijakan masing-masing sehingga sangat rawan menimbulkan konflik kepentingan. Penegakan hukum yang tidak terkoordinasi merupakan salah satu kendala dalam penanggulangan kejahatan Illegal Fishing. Proses peradilan mulai dari penyidikan hingga ke persidangan membutuhkan biaya yang sangat besar, proses hukum yang sangat panjang dan sarana prasarana yang sangat memadai membutuhkan keahlian khusus dalam penanganan kasus tersebut. Dalam satu Instansi tentu tidak memiliki semua komponen. Data, informasi ataupun sarana dan prasarana yang dibutuhkan dalam rangka penegakan hukum, oleh karena itu diperlukan koordinasi dan kerjasama yang sinergis antar Instansi yang terkait dalam upaya penegakan hukum terhadap Illegal Fishing ini.

Dengan banyaknya tindak pidana lain yang juga terjadi bersamaan terjadi dalam tindak pidana perikanan atau perbarengan tindak pidana (Concursus). Menurut ketentuan Kitab Undang-Undang Hukum Pidana (KUHP), perbuatan pidana itu terbagi menjadi dua macam yaitu kejahatan (misdrijven) dan pelanggaran (overtredingen). Dari segi kodifikasinya, kejahatan diatur dalam buku kedua KUHP, sedangkan pelanggaran diatur tersendiri dalam buku ketiga KUHP. Dari sisi akibat hukumnya, kejahatan lebih didominasi dengan ancaman pidana penjara bagi pelakunya. Adapun untuk perbuatan yang termasuk ketegori pelanggaran, pelakunya dijatuhi hukuman berupa kurungan dan denda.

Dengan demikian maka terdapat perbedaan pada kedua tindak pidana tersebut. Perbuatan pidana di atas masing-masing mempunyai konsekuensi tersendiri yang tidak sama. Akan tetapi, pada kenyataannya seringkali ditemukan adanya suatu perbuatan kejahatan yang bersamaan dengan kejahatan lain. Ada juga satu perbuatan pelanggaran yang disertai dengan pelanggaran lain. Atau bahkan perbuatan kejahatan yang bersamaan dengan pelanggaran dan sebaliknya. Ada kalanya suatu tindakan pidana yang ternyata diatur dalam lebih dari satu ketentuan pidana. Kejadian seperti diatas biasa disebut perbarengan.

Pengertian gabungan tindak pidana dalam bahasa. Indonesia dalam bahasa Belanda juga disebut sebagai Samenloop van strafbaar feiten dan sedangkan concursus 
berasal dari bahasa Latin. Dikalangan para sarjana digunakan beberapa terjemahan seperti gabungan tindak pidana atau rentetan peristiwa pidana dan masih banyak lagi. Di samping dari pada beberapa perbuatan pidana yang masing-masing merupakan perbuatan berdiri sendiri (kejahatan atau pelanggaran) tetapi diantara perbuatan itu ada hubungannya satu sama lain yang harus dianggap sebagai satu perbuatan berlanjut.

Tindak pidana perikanan menjadi tindak pidana asal (predicate crime) pada tindak pidana lainnya. Tindak pidana perikanan yang juga merupakan kejahatan ekonomi sehingga dalam pelaksanaan penegakan hukumnya dianggap harus mengejar pengembalian atas kerugian yang Negara derita oleh tindak pidana yang terjadi. Pendekatan multidoor system bermula sejak tahun 2012 yang diprakarsai oleh Unit Kerja Presiden Bidang Pengawasan dan Pengendalian Pembangunan (UKP4) yang mana UKP4 merupakan kelanjutan dari Unit Kerja Presiden Pengelolaan Program dan Reformasi (UKP3R), pendekatan ini kemudian dituangkan dalam Nota Kesepahaman Bersama antara Kementerian Lingkungan Hidup (KLH), Kementerian Kehutanan (KemenHut) , Pusat Pelaporan dan Analisis Transaksi Keuangan (PPATK), Kepolisian RI serta Kejaksaan RI untuk menangani kasus terkait sumber daya alam dan kehutanan

\section{METODE PENELITIAN}

Berdasarkan isu hukum yang dikaji, penelitian ini diarahkan pada kekhasan ilmu hukum yang sifatnya normatif ${ }^{2}$, sehingga tipe penelitian tesis ini adalah penelitian hukum normatif, yaitu penelitian yang mengkaji ketentuan hukum positif tertulis secara sitematis terkait dengan penanganan tindak pidana perikanan. Di dalam penelitian hukum terdapat beberapa pendekatan Penelitian ini adalah penelitian hukum. Penelitian hukum dilakukan untuk mencari pemecahan atas isu hukum yang timbul. Hasil yang hendak dicapai adalah memberikan preskripsi mengenai apa yang seyogyanya. ${ }^{3}$ Pendekatan yang digunakan adalah pendekatan peraturan perundangundangan (Statute approach), pendekatan konseptual (conceptual approach), pendekatan serta pendekatan kasus (Case approach).

2 Philipus M Hadjon dan Tatiek Sri Djatmiati, Argumentasi Hukum, Gaja Mada University Press, 2005, h.1.

3 Peter Mahmud Marzuki,(III), Penelitian Hukum, Kencana Predana Media Group, Jakarta, 2009, h. 89. 


\section{HASIL PENELITIAN DAN PEMBAHASAN}

A. Multi-Rezim Hukum (Multi door Approach) dalam pemberantasan tindak pidana perikanan.

Multi-rezim hukum adalah pendekatan berbagai macam undang-undang dalam penegakan hukum. Pendekatan ini merupakan salah satu cara atau langkah aparatur penegakan hukum untuk mendorong supremasi hukum yang lebih baik dengan menjamin bahwa semua tindak pidana yang terjadi di wilayah Negara Kesatuan Republik Indonesia dapat di tangani dengan tepat dan proporsional. Dalam Undangundang No. 45 tahun 2009 tentang Perubahan atas Undang undang 31 tahun 2004 tentang Perikanan Pasal 73 disebutkan bahwa :

(1) Penyidikan tindak pidana di bidang perikanan dilakukan oleh Penyidik Pegawai Negeri Sipil Perikanan, Perwira TNI AL, dan Pejabat Polisi Negara Republik Indonesia.

(2) Penyidik sebagaimana dimaksud pada ayat (1) dapat melakukan koordinasi.

(3) Untuk melakukan koordinasi dalam penanganan tindak pidana di bidang perikanan, Menteri dapat membentuk forum koordinasi. ${ }^{4}$

Undang-Undang No. 31 Tahun 2004 tentang Perikanan telah memuat regulasi baik mengenai tindak pidana di bidang perikanan maupun hukum acara pidananya. Tindak pidana di bidang perikanan diatur dalam Bab XV, Pasal 84 s/d Pasal 104. Sedangkan mengenai hukum acara dalam penyidikan, penuntutan maupun pemeriksaan di sidang pengadilan perikanan dilakukan menurut Undang-Undang No. 8 Tahun 1981 tentang Hukum Acara Pidana (KUHAP) kecuali telah ditentukan secara khusus dalam Undang Undang Perikanan. Ketentuan khusus dalam tahap penyidikan tindak pidana di bidang perikanan yaitu penyidikan yang melibatkan 3 (tiga) instansi yang berwenang. Berdasarkan ketentuan Pasal 73 ayat (1) Undang Undang Perikanan, penyidikan tindak pidana di bidang perikanan di wilayah pengelolaan perikanan Negara Republik Indonesia dilakukan oleh Penyidik Pegawai Negeri Sipil (PPNS) Perikanan, Penyidik Perwira Tentara Nasional Indonesia Angkatan Laut (TNI AL), dan/atau Penyidik Kepolisian Negara Republik Indonesia (Polri).

Dalam Undang-Undang No. 45 Tahun 2009 tentang Perubahan Atas UndangUndang No. 31 Tahun 2004 tentang Perikanan, Pasal 73 mengalami perubahan, dengan menambah 2 (dua) ayat, yaitu ayat (2) dan ayat (3). Ayat (2) Pasal 73 menyebutkan

${ }^{4}$ Republik Indonesia, Undang-Undang tentang Perubahan atas Undang-Undang No. 31 tahun 2004 tentang Perikanan, Pasal 73. 
“Selain penyidik TNI AL, Penyidik Pegawai Negeri Sipil Perikanan berwenang melakukan penyidikan terhadap tindak pidana di bidang perikanan yang terjadi di Zona Ekonomi Eksklusif Indonesia (ZEEI). Sedangkan ayat (3) nya "Penyidikan terhadap tindak pidana di bidang perikanan yang terjadi di pelabuhan perikanan, diutamakan dilakukan oleh Penyidik Pegawai Negeri Sipil Perikanan.

Rumitnya pembagian kewenangan penanganan tindak pidana perikanan dan berkembangnya modus operandi tindak pidana perikanan yang ada, Undang UndangUndang No. 45 Tahun 2009 tentang Perubahan atas Undang-Undang No. 31 Tahun 2004 tentang Perikanan mengatur perlunya koordinasi antar stakeholder kelautan dan perikanan. Pada pasal 73 ayat (4) dan (5) Undang-Undang Undang No. 45 Tahun 2009 tentang Perubahan atas Undang-Undang No. 31 Tahun 2004 tentang Perikanan disebutkan bahwa ${ }^{5}$ :

(4) Penyidik sebagaimana dimaksud pada ayat (1) dapat melakukan koordinasi dalam penanganan penyidikan tindak pidana di bidang perikanan.

(5) Untuk melakukan koordinasi dalam penanganan tindak pidana di bidang perikanan sebagaimana dimaksud pada ayat (4), Menteri membentuk forum koordinasi.

Peran forum koordinasi penanganan tindak pidana di bidang perikanan yang diisi berbagai unsur penegak hukum yang diantaranya Kepolisian RI, TNI AL, Kementerian Hukum dan HAM, Kejaksaan Agung, Mahkamah Agung, Kementerian Perhubungan, Kementerian Keuangan dan lain lain dianggap dapat menjadi wadah koordinasi dalam menekan tindak pidana perikanan dari multi sektor sehingga pelaku tindak pidana perikanan menjadi tidak lagi memiliki celah untuk menghindar dari jerat hukum. namun dalam perkembangannya dianggap belum menghasilkan hasil yang maksimal dalam penanganan tindak pidana di bidang perikanan. Sementara itu perkembangan modus operandi yang semakin komplek menuntut pemerintah lebih keras menjaga sumber daya kelautan dan perikanan.

Semakin berkembangnya pelanggaran hukum di bidang perikanan, maka penegakan hukum dalam bidang pengelolaan perikanan yang berkelanjutan (sustainable fisheries management) saja tidak cukup. Dengan pertimbangan bahwa pelanggaran dan kejahatan dibidang perikanan khususnya tindakan penangkapan ikan

${ }^{5}$ Republik Indonesia, Undang-Undang No.45 Tahun 2009 tentang Perubahan atas Undang-Undang No. 31 tahun 2004 tentang Perikanan, Pasal 73. 
secara ilegal (Illegal Fishing) sudah sangat memprihatinkan, Presiden Joko Widodo pada tanggal 19 Oktober 2015 telah menandatangani Peraturan Presiden (Perpres) Nomor 115 Tahun 2015 tentang Satuan Tugas atau Satgas Pemberantasan Penangkapan Ikan Secara Ilegal atau illegal fishing.

Berbeda dengan forum koordinasi penanganan tindak pidana di bidang perikanan yang hanya sebagai wadah koordinasi masing-masing penegak hukum di laut. Satuan Tugas atau Satgas Pemberantasan Penangkapan Iklan Secara Ilegal atau illegal fishing memiliki kewenangan pemanfaatan personil dan peralatan operasi milik anggota satgas sampai pada penyidikan, penuntutan maupun pengumpulan data dan informasi yang dibutuhkan sebagai upaya penegakan hukum dengan institusi terkait termasuk tidak terbatas pada Kementerian Kelautan dan Perikanan, Kementerian Keuangan, Kementerian Luar Negeri, Kementerian Perhubungan, Tentara Nasional Indonesia Angkatan Laut, Kepolisian Negara Republik Indonesia, Kejaksaan Agung Republik Indonesia, Badan Keamanan Laut, Pusat Pelaporan dan Analisis Transaksi Keuangan, Badan Intelijen Negara.

Melaksanakan komando dan pengendalian yang meliputi kapal, pesawat udara, dan teknologi lainnya dari Tentara Nasional Indonesia Angkatan Laut, Kepolisian Negara Republik Indonesia, Kementerian Kelautan dan Perikanan, serta Badan Keamanan Laut yang sudah berada di dalam Satgas. Satgas membentuk Tim Gabungan yang dipimpin Komandan Sektor (On Scene Commander) di laut dan melaksanakan operasi penegakan hukum pemberantasan penangkapan ikan secara ilegal berdasarkan data intelijen.

Pendekatan multi-rezim hukum atau multidoor approach yang diterapkan oleh Satgas 115 tersebut membawa konsekuensi dan memiliki tantangan tersendiri, antaralain bagi para penyidik pegawai negeri sipil (PPNS) perikanan sebagai tindak pidana (predicate crime) yang dituntut untuk harus mampu menguasai berbagai ketentuan peraturan perundang-undangan yang berkaitan satu sama lain secara komprehensif dan holistik. Menyebabkan peningkatan profesionalitas dan kapabilitas aparat penegak hukum yang tergabung dalam Satgas 115 menjadi sebuah keniscayaan.

Dalam pelaksanaan penegakan hukum Menteri Kelautan dan dan Perikanan selaku Komandan satgas 115 menerbitkan Peraturan Menteri Kelautan dan dan Perikanan No. 37/PERMEN-KP/2017 tentang Standar operasional prosedur penegakan hukum satuan tugas pemberantasan penangkapan ikan secara illegal (Illegal fishing), dimana didalam peraturan menteri tersebut merupakan acuan bagi anggota Satuan Tugas Pemberantasan Penangkapan Ikan secara Ilegal (Illegal Fishing) dalam 
melaksanakan operasi dan penegakan hukum terhadap kejahatan di bidang perikanan sesuai ketentuan hukum nasional dan hukum internasional.

\section{B. Peradilan Perikanan dalam penerapan multi-rezim hukum.}

Undang-Undang Perikanan dianggap masih memiliki beberapa kelemahan. Lahirnya Undang-Undang Perikanan yang di dalamnya mengamanatkan dibentuknya pengadilan perikanan juga sempat mendapat sorotan publik. Tak kurang Ketua Mahkamah Agung sendiri telah dibuat kaget dengan lolosnya ketentuan dalam UndangUndang tersebut mengenai pembentukan pengadilan perikanan, yang konon pembahasannya tidak melibatkan pihak Mahkamah Agung. Kritik terhadap pembentukan pengadilan perikanan juga dilontarkan oleh pakar hukum pidana Indriyanto Seno Adji yang menilai bahwa pembentukan pengadilan khusus hanya akan menimbulkan kesimpangsiuran dan inkonsistensi atas asas penyatuatapan, serta melanggar sistematisasi lembaga peradilan yang mengakui MA sebagai top judicial. Selain itu dalam pengaturan dan pelaksanaan penyidikan, tidak ada ketentuan yang mengatur mengenai mekanisme koordinasi antara instansi penyidik. ${ }^{6}$

Akan tetapi, pembentukan pengadilan perikanan pada dasarnya dilandasi oleh semangat mengatasi krisis ketidakberdayaan lembaga-lembaga peradilan yang ada dalam menjawab berbagai persoalan hukum yang terkait penegakan hukum pelanggaran di bidang perikanan. Selain itu dengan semakin kompleksnya permasalahan-permasalahan di bidang perikanan, dibutuhkan lembaga peradilan khusus yang lebih profesional yang didukung dengan sumber daya manusia yang menguasai persoalan khusus di bidang perikanan. ${ }^{7}$

Permasalahan yang muncul kemudian yaitu ketika daerah yang tidak memiliki peradilan perikanan harus menyelesaikan permasalahan tindak pidana perikanan melalui pengadilan negeri. Sebagaimana diketahui, bahwa dalam memeriksa, mengadili dan memutus tindak pidana perikanan di pengadilan perikanan menggunakan ketentuan hukum acara yang khusus dari ketentuan yang umum pada Undang-Undang No. 8 Tahun 1981 tentang KUHAP. ${ }^{8}$

6 Deskripsi Konsepsi dari Pemerintah dalam Pengusulan Perubahan Kedua UndangUndang Nomor 31 Tahun 2004 dalam Program Legislasi Nasional 2015-2019 lihat http://dpr.go.id/prolegnas/deskripsi-konsepsi2/id/93, diakses tanggal 05 April 2019.

7 Analisis dan Evaluasi Hukum Tentang Pengadilan Perikanan, BPHN Departemen Hukum dan HAM RI, Jakarta, h.2.

${ }^{8}$ Gatot Supramono, Hukum Acara Pidana \& Hukum Pidana Di Bidang Perikanan (Jakarta: Rineka Cipta, 2011). h. 66. 
Dengan adanya pengadilan khusus perikanan di beberapa wilayah tersebut diatas, bagaimana peluang penerapan pendekatan multi-rezim hukum (multidoor approach) dalam pemberantasan Illegal Fishing? Apakah penerapan pendekatan multirezim hukum (multidoor approach) tepat dalam pemberantasan Illegal Fishing mengingat ada potensi perkara tidak diterima karena nebis in idem? Permasalahan timbul dalam kompetensi absolut pengadilan perikanan yang pada Pasal 71 ayat (1) hanya berwenang memeriksa, mengadili, dan memutus tindak pidana di bidang perikanan. Perkembangan saat ini tindak pidana perikanan sering dijadikan modus atau saling berkaitan dengan tindak pidana lainnya. Penegak hukum menemukan kejahatan dan pelanggaraan lain seperti masalah keimigrasian, perdagangan orang (human traficking), tenaga kerja ilegal, tenaga kerja di bawah umur, pemilikan obat dan senjata ilegal, atau bahkan narkoba. Dalam hal terjadi temuan adanya kasus pidana non perikanan, saat ini tentu dibutuhkan penanganan dan pemeriksaan di peradilan yang berbeda, yakni peradilan umum dan peradilan perikanan. Mengingat kewenangan Pengadilan Perikanan hanya mencakup tindak pidana bidang perikanan sebagaimana diatur dalam Undang-Undang Perikanan maka saat ada tindak pidana non perikanan yang ditemukan, pengadilan perikanan tidak memiliki kewenangan untuk menangani perkara non perikanan dan mengharuskan kasus non perikanan ini ditangani oleh peradilan umum.

Model pencegahan dan pemberantasan illegal fishing dan fishing crime dapat dilakukan dengan dua track. Pertama, Multi-rezim hukum. Upaya pencegahan dan pemberantasan illegal fishing dapat dilakukan dengan menggunakan rezim hukum lain selain rezim illegal fishing dalam undangundang perikanan. Untuk mencegah dan memberantas praktik transaksi BBM ilegal (illegal transaction of fuel) di laut maka dapat digunakan rezim hukum minyak dan gas bumi sedangkan untuk tindak pidana di bidang keimigrasian (immigration related crime) maka dapat digunakan undangundang keimigrasian. Terhadap tindak pidana di bidang bea cukai termasuk penyelundupan obat terlarang, penyelundupan satwa terlarang (customs related crime including smugglings of drugs, protected species, vessel spare parts and other goods) dapat digunakan undang-undang kepabeanan, undang-undang anti narkoba, dll. Terhadap tindak pidana pencucian uang (money laundering) maka digunakan rezim hukum anti pencucian uang. Terhadap tindak pidana perdagangan obat terlarang (illicit drugs trafficking) maka dapat digunakan undang undang anti perdagangan orang. Terhadap tindak pidana perburuhan (Labor related crimes: modern slavery, human trafficking and child labor), maka dapat digunakan undang undang ketenagakerjaan, 
undang-undang anti perdagangan orang, dan undang-undang perlindungan. Begitu juga pada tindak pidana bidang perpajakan dan tindak pidana korupsi maka pelaku kejahatan dapat dikejar dengan undang-undang perpajakan dan undang undang pemberantasan korupsi. ${ }^{9}$

Penerapan pendekatan multi-rezim hukum (multidoor approach) di bidang perikanan dilakukan dengan penyidikan menggunakan beberapa undang-undang secara pararel, berkas perkara perikanan dipisah dengan berkas perkara lainnya sehingga proses penyidikan dan penuntutan dilakukan secara pararel. Namun dalam pelaksanaan pembuktian terhadap beberapa tindak pidana lainnya terkait perikanan harus dilakukan di peradilan umum dikarenakan kewenangan absolut pengadilan perikanan yang hanya berwenang memeriksa, mengadili, dan memutus tindak pidana di bidang perikanan. Oleh karena itu pelaksanaan pembuktian pada pendekatan multirezim hukum (multidoor approach) atas tindak pidana perikanan dan tindak pidana lainnya terkait perikanan menjadi lebih tepat dilakukan pada peradilan umum. Sehingga dalam penyidikan, penuntutan dan pemeriksaan di tingkat pengadilan akan lebih memungkinkan bagi terlaksananya asas sederhana, cepat dan biaya ringan sebagaimana diamanatkan oleh Pasal 4 ayat (2) Undang-Undang Pokok Pokok Kekuasaan Kehakiman.

\section{Perbarengan Tindak Pidana pada tindak pidana perikanan}

Gabungan melakukan tindak pidana sering diistilahkan dengan concursus atau samenloop. Untuk memberikan gambaran yang lebih jelas mengenai pengertian perbarengan tindak pidana maka perlu diketahui bagaimana pendapat para sarjana hukum dalam memberikan definisi mengenai perbarengan tindak pidana ini. Menurut KUHP gabungan melakukan tindak pidana sering diistilahkan dengan Samenloop van Strafbare Feiten yaitu satu orang yang melakukan beberapa peristiwa pidana. ${ }^{10}$

Pengertian perbarengan (concursus) di dalam KUHP belum dijelaskan secara langsung di dalam pasal-pasal tetapi unsur-unsur dari perbarengan ada dalam pasal KUHP. Unsur-unsur perbarengan (concursus) yang dibagi atas tiga bagian yaitu pertama; concursus idealis, terdapat dalam Pasal 63 KUHP yang mengatakan bahwa suatu perbuatan masuk dalam lebih dari satu aturan pidana, kedua; perbuatan berlanjut, terdapat dalam Pasal 64 KUHP yang mengatakan bahwa apabila seseorang melakukan beberapa perbuatan tersebut masing-masing merupakan kejahatan atau

${ }_{9}^{9}$ Daud Silalahi, Op Cit, h.24.

${ }^{10}$ E. Utrecht, Hukum Pidana II , Pustaka Tinta Mas ,Surabaya, 1994, h. 137. 
pelanggaran antara perbuatan-perbuatan itu ada hubungan sedemikian rupa sehingga harus dipandang sebagai satu perbuatan berlanjut, sedangkan yang terakhir adalah concursus realis terdapat dalam Pasal 65 KUHP yang mengatakan apabila seseorang melakukan perbuatan masing-masing perbuatan itu berdiri sendiri sebagai suatu delik (kejahatan/pelanggaran).

Drs. P.A.F. Lamintang, SH., menyatakan sebagai berikut :

"... Perlu diketahui bahwa orang hanya dapat berbicara mengenai adanya suatu samenloop van straf baarefeiten, apabila di dalam suatu jangka waktu tertentu, seseorang telah melakukan lebih dari satu perbuatan terlarang dan di dalam jangka waktu tersebut orang yang bersangkutan belum pernah dijatuhi hukuman oleh pengadilan, karena salah satu dari prilaku-prilaku yang telah ia lakukan. Apabila di dalam jangka waktu ..., melainkan mungkin saja mengenai suatu pengulangan atau suatu recidive seperti dimaksudkan dalam Bab XXXI dari Buku II KUHP".11

Salah satu kasus perbarengan (concursus) yang dapat diuji objektivitas hakim dalam menjatuhkan putusan yaitu kasus perbarengan perbuatan (concursus realis), di lihat dari kasus perbarengan perbuatan (concursus realis) hubungan delik yang satu dengan delik yang lainnya masing-masing berdiri sendiri yang dilakukan oleh satu orang. Pada kasus concursus realis secara teori, hakim dalam mempertimbangkan putusan tidak melihat pada jenis atau hubungan antara delik yang satu dengan delik yang lainnya. Hakim dalam memutus suatu perkara pada kasus concursus realis harus sesuai dengan ketentuan yang ada pada Pasal 65 sampai dengan Pasal 71 KUHP. Ketentuan tersebut mengatur sistem pemberian sanksi pada concursus realis. Di lihat dari pasal yang mengatur pemberian sanksi pada kasus concursus realis, sanksi yang diberikan bermacam macam dilihat dari jenis delik yang dilakukan.

Hans Tangkau menyatakan : ${ }^{12}$

"Kesamaannya adalah baik perbuatan berlanjut maupun perbarengan beberapa perbuatan, adalah kedua-duanya pelaku melakukan beberapa (lebih dari satu) tindak pidana. Sedangkan perbedaannya ialah dalam perbuatan berlanjut adalah beberapa perbuatan yang dilakukan itu harus dipandang satu perbuatan, karena ada hubungan antara satu dengan yang lainnya, sedangkan dalam perbarengan beberapa perbuatan adalah beberapa perbuatan yang dilakukan itu haruslah dipandang masing-masing berdiri sendiri. Perbedaan dalam hukuman antara keduanya ialah dalam perbuatan berlanjut hanya dikenakan satu hukuman saja tanpa adanya pemberatan, sedangkan dalam perbarengan perbuatan, biarpun hanya dikenakan satu hukuman sama dengan perbuatan berlanjut, akan tetapi maksimal hukumannya dapat ditambah sepertiga dari ancaman hukuman

11 P.A.F.Lamintang, Dasar-Dasar Hukum Pidana, Sinar Baru, Bandung, 1984, h.

12 Hans Tangkau, Gabungan Beberapa Perbuatan Pidana dan Masalah

Penghukumannya, Fakultas Hukum Universitas Sam Ratulangi, Manado, 2007, h. 1. 
terberat. Dengan kata lain, ancaman hukuman terhadap concursus realis adalah lebih berat dari ancaman hukuman terhadap perbuatan berlanjut."

Pelaksanaan concursus realis pada pemberantasan Illegal Fishing salah satunya terjadi pada perkara YONGYUT NITIWONGCHAROEN selaku Nakhoda dari KM. Antasena 838, pada hari Rabu tanggal 26 Maret tahun 2014 yang melakukan usaha dan/atau kegiatan pengelolaan Perikanan tanpa mematuhi ketentuan tentang daerah, jalur dan waktu atau musim penangkapan ikan, sebagaimana dimaksud dalam Pasal 7 ayat (2) huruf c Undang-undang RI Nomor 45 Tahun 2009 tentang Perubahan Atas Undang-undang RI Nomor 31 Tahun 2004 Tentang Perikanan. Operasi pengawasan Satuan Sumber Daya Kelautan dan Perikanan (SDKP) dengan menggunakan kapal Hiu Macan 006 di perairan Laut Arafura (Teritorial Perikanan Republik Indonesia).

Dari hasil pemeriksaan fisik kapal maupun dokumen-dokumen diketahui kapal tersebut merupakan kapal penangkap ikan dengan nama KM. Antasena 838 milik PT. Pusaka Benjina Nusantara, berbendera Indonesia, terbuat dari kayu dengan tonage kapal 143 (seratus empat puluh tiga) GT dan membawa 24 orang anak buah kapal $(\mathrm{ABK})$, terdiri dari 4 orang warga Negara Indonesia dan 20 orang warga negara asing (Thailand) dinakhodai oleh Tersangka YONGYUT NITIWONGCHAROEN, kapal KM.Antasena 838 bermuatan \pm 120 ton ikan.

Pelanggaran yang dilakukan oleh KM. Antasena 838 disangkakan dengan Pasal 100 Juncto Pasal 7 ayat (2) huruf c Undang-undang RI Nomor 45 Tahun 2009 tentang Perubahan Atas Undang-undang RI Nomor 31 Tahun 2004 Tentang Perikanan dimana sanksi atas perbuatan tersebut sesuai dengan Pasal 100 adalah ;

"Setiap orang yang melanggar ketentuan yang ditetapkan sebagaimana dimaksud dalam Pasal 7 ayat (2) dipidana dengan pidana denda paling banyak $R p$ 250.000.000,00 (dua ratus lima puluh juta rupiah)."

Hukuman atau sanksi maksimal sesuai dengan Pasal 100 Juncto Pasal 7 ayat (2) huruf c Undang-undang RI Nomor 45 Tahun 2009 tentang Perubahan Atas Undangundang RI Nomor 31 Tahun 2004 Tentang Perikanan dianggap belum cukup dan tidak memenuhi rasa keadilan akan akibat yang ditimbulkan oleh KM.Antasena 838 di Laut Arafura (Teritorial Perikanan Republik Indonesia). Dalam putusan kasasi di Mahkamah Agung dengan No. $41 \mathrm{~K}$ /Pid.Sus/ 2015, terpidana YONGYUT NITIWONGCHAROEN dihukum dengan pidana denda sebesar Rp250.000.000.00 (dua ratus lima puluh juta rupiah) subsidair 6 (enam) bulan kurungan.

Dalam penyidikan tindak pidana perikanan atas YONGYUT NITIWONGCHAROEN selaku Nakhoda dari KM. Antasena 838 oleh Stasiun PSDKP Tual juga ditemukan tindak pidana lain yaitu Tindak Pidana Perdagangan Orang (TPPO), 
sehingga YONGYUT NITIWONGCHAROEN juga di sangkakan pada berkas perkara Tindak Pidana Perdagangan Orang (TPPO). Dalam putusannya Pengadilan Negeri Tual No.105/Pid.Sus/2015/PN-Tul Yang Bersanagkutan dinyatakan:13

1. Menyatakan Terdakwa Mr. YOUNGYUT NITIWONGCHAROEN alias YUT alias TAI YUT telah terbukti secara sah dan meyakinkan menurut hukum bersalah melakukan Tindak Pidana "Perdagangan Orang" sebagaimana yang diatur dalam dakwaan Primair;

2. Menjatuhkan Pidana Terhadap Terdakwa Mr. YOUNGYUT NITIWONGCHAROEN alias YUT alias TAI YUT dengan pidana penjara selama 3 (tiga) tahun dan pidana denda sebesar Rp. 160.000.000,00 (sertus enam puluh juta rupiah) dengan ketentuan apabila denda tersebut tidak dibayar diganti dengan pidana kurungan selama 3 (tiga) bulan;

3. Mewajibkan kepada Perusahaan Silversea Fishery Co melalui Terdakwa Mr. YOUNGYUT NITIWONGCHAERON alias YUT alias TAI YUT untuk membayar Restitusi kepada korban yaitu AUNG THEIN TUN dan MIN HTIKE, yang keseluruhannya sejumlah Rp. 129.900.000,00 (seratus dua puluh sembilan juta sembilan ratus ribu rupiah), jika dalam waktu 14 (empat belas) hari terhitung sejak putusan ini telah memperoleh kekuatan hukum tetap, tidak dilaksanakan Restitusi, maka Pengadilan memerintahkan Penuntut Umum untuk menyita harta kekayaan terpidana dan melelang harta kekayaan tersebut untuk pembayaran Restitusi dan apabila tidak mampu membayar maka dikenai pidana kurungan pengganti selama 1 (satu) tahun.

4. Menetapkan masa penahanan yang telah dijalani oleh terdakwa dikurangkan seluruhnya dari pidana yang dijatuhkan.

5. Memerintahkan agar terdakwa tetap berada dalam tahanan.

6. Menetapkan barang bukti berupa :

1. 4 (empat) buah kapal beserta dokumennya :

a. KM.ANTASENA 311 GT 108 beserta dokumenya :

b. KM.ANTASENA 141 GT 202 beserta dokumennya :

c. KM.ANTASENA 142 GT 330 beserta dokumenya :

d. KM.ANTASENA 309 GT 111 beserta dokumenya :

Digunakan dalam perkara atas Terdakwa YOPI HANORSIAN alias YOPI.

${ }^{13}$ Putusan kasasi Mahkamah Agung atas perkara tindak pidana perdagangan orang No. 105/Pid.Sus/ 2015/PN.Tul dengan terpidana Yongyut Nitiwongcharoen. 
Selain YOPI HANORSIAN alias YOPI yang merupakan mantan Quality Control di PT. PBR juga disangkakan pada HERMANWIR MARTINO alias HERMAN yang bertindak sebagai Pimpinan Cabang PT. PBR Benjina/Pjs. Site Ops Head Departement. Dalam putusannya keterlibatan YOPI HANORSIAN alias YOPI dan meyakinkan menurut hukum bersalah membantu melakukan "Tindak Pidana Perdagangan Orang" sebagaimana diatur dan diancam pidana dalam dakwaan Primair melanggar Pasal 2 ayat (2) Jo. Pasal 10 Undang-Undang Nomor 21 tahun 2007 tentang Pemberantasan Tindak Pidana Perdagangan Orang Jo. Pasal 56 ayat (1) Kitab Undang- Undang Hukum Pidana.

Dalam putusan Pengadilan Tual No. 111/Pid.Sus/2015/PN.TUL YOPI HANORSIAN alias YOPI dinyatakan :

Menjatuhkan pidana terhadap terdakwa YOPI HANORSIAN alias YOPI berupa pidana penjara selama 3 (tiga) tahun dan 6 (enam) bulan dikurangi selama terdakwa berada dalam tahanan dengan perintah supaya terdakwa tetap ditahan dan ditambah dengan pidana denda sebesar Rp. 240.000.000,- (dua ratus empat puluh juta rupiah) subsidiair selama 3 (tiga) bulan kurungan. ${ }^{14}$

Sedangkan HERMANWIR MARTINO alias HERMAN yang bertindak sebagai Pimpinan Cabang PT. PBR Benjina/Pjs. Site Ops Head Departement di vonis oleh Pengadilan Negeri Tual dengan perkara No. 112/Pid.Sus/2015/PN.TUL dinyatakan :

Menjatuhkan pidana terhadap terdakwa HERMANWIR MARTINO alias HERMAN berupa pidana penjara selama 4 (empat) tahun dan 6 (enam) bulan dikurangi selama terdakwa berada dalam tahanan dengan perintah supaya terdakwa tetap ditahan dan ditambah dengan pidana denda sebesar Rp. 240.000.000,- (dua ratus empat puluh juta rupiah) subsidiair selama 3 (tiga) bulan kurungan. ${ }^{15}$

Penanganan tindak pidana terhadap KM. Antasena 838 dan PT. Pusaka Benjina Resources merupakan contoh nyata penegakan hukum dengan pendekatan multi-rezim hukum (multi door approach), sehingga tidak cukupnya atau belum memenuhi keadilan terhadap masyarakat dan Negara dalam kerugian yang terjadi atas kejahatan pada tindak pidana perikanan dapat terus dikejar untuk memenuhi rasa keadilan dan meminimalisir lolosnya para pelaku tindak pidana perikanan atau tindak pidana

14 Putusan Pengadilan Negeri Tual atas perkara tindak pidana perdagangan orang No. 111/Pid.Sus/2015/PN.TUL dengan terpidana Yopi Hanorsian Alias Yopi.

15 Putusan Pengadilan Negeri Tual atas perkara tindak pidana perdagangan orang No.112/Pid.Sus/2015/PN.TUL dengan terpidana Hermanwir Martino Alias Herman. 
lainnya akibat kewenangan limitatif Penyidik Pegawai Negeri Sipil (PPNS) Perikanan dan rendahnya sanksi maupun denda pelaku tindak pidana atas pengembalian kerugian Negara yang diakibatkan illegal fishing.

Hukuman atau sanksi dengan multi-rezim hukum (multi door approach) dalam perkara diatas berperan menjamin bahwa seluruh tindak pidana yang terjadi di KM. Antasena 838 dan PT. Pusaka Benjina Resources baik perkara tindak pidana perikanan maupun Tindak Pidana Perdagangan Orang (TPPO) di vonis secara pararel sehingga tidak ada tindak pidana yang dilakukan oleh Nakhoda KM. Antasena 838 YOUNGYUT NITIWONGCHAERON alias YUT alias TAI YUT lolos dari jeratan hukum.

Tindak pidana yang dilakukan YOUNGYUT NITIWONGCHAERON alias YUT alias TAI YUT yaitu Tindak Pidana perikanan yang dilakukan penyidikannya oleh Penyidik Pegawai Negeri Sipil (PPNS) Perikanan Kementerian Kelautan dan Perikanan dan Tindak Pidana Perdagangan Orang (TPPO) yang penyidikannya dilakukan oleh kepolisian Negera Republik Indonesia dengan berkas perkara terpisah menjadikan perkara atas YOUNGYUT NITIWONGCHAERON alias YUT alias TAI YUT lepas dari Asas Ne Bis In Idem. Penerapan multi-rezim hukum (multidoor approach) dibidang perikanan ini tidak hanya dapat menjerat Nakhoda atau KKM (Kepala kamar Mesin) di kapal, jika ditemukan tindak pidana lain seperti perdagangan orang (TPPO) makan agen maupun direksi perusahaannya dapat dijerat dengan undang-undang Tindak Pidana Perdagangan Orang. Berkas perkara perikanan dipisah dengan berkas perkara lain, sehingga proses penyidikan dan penuntutan dilakukan secara pararel.

Concursus atau perbarengan tindak pidana dalam perkara tersebut memang tindak diputus dengan hanya satu ketukan palu hakim namun melalui beberapa persidangan berbeda seperti umumnya perbarengan tindak pidana lainnya, pembagian tugas penyidikan sesuai kewenangan antara Penyidik Pegawai Negeri Sipil Perikanan dan Penyidik Kepolisian sudah dilakukan dengan tepat. Pemisahan pembuktian pada persidangan yang terjadi merupakan salah satu kendala atas kewenangan absolut pengadilan khusus perikanan yang memang hanya berwenang memeriksa, mengadili, dan memutus tindak pidana di bidang perikanan, sementara dalam perkara tersebut diatas ada 1 (satu) tindak pidana lain yaitu Tindak Pidana Perdagangan Orang (TPPO). namun tujuan penerapan pendekatan multi-rezim hukum pada tindak pidana perikanan telah diaplikasikan untuk memastikan bahwa tidak ada tindak pidana yang tidak diadili sehingga memastikan asa kepastian hukum dan menjawab rasa keadilan di masyarakat. 


\section{KESIMPULAN DAN SARAN}

Berdasarkan hasil penelitian dan pembahasan pada uraian sebelumnya, penelitian ini membuat kesimpulan bahwa pendekatan Multi-rezim hukum (multi door approach) dalam penanganan tindak pidana perikanan merupakan langkah yang dilakukan Negara Indonesia dalam memerangi tindak pidana perikanan maupun tindak pidana lain terkait perikanan. Tindak pidana perikanan yang acap kali diikuti oleh tindak pidana lainnya menggugah Indonesia mencari solusi untuk meminimalisir kemungkinan lolosnya pelaku kejahatan perikanan maupun kejahatan terkait perikanan dan menjadikan tindak pidana perikanan sebagai kejahatan luar biasa (extra ordinary crime) serta kejahatan lintas Negara yang terorganisir (transnasional organized crime). Concursus Realis (perbarengan tindak pidana) yang terjadi dalam tindak pidana perikanan dan tindak pidana terkait perikanan tepat untuk di terapkan dalam penanganan tindak pidana perikanan dan tindak pidana terkait perikanan secara pararel sehingga terlepas dari gugurnya kewenagan penuntutan dan pelaksanaan pidana ( $N e$ bis in idem) dan menjamin semua tindak pidana yang terjadi mendapatkan sanksi yang tepat dan proporsional.

Berdasarkan kesimpulan diatas, maka dapat disarankan penerapan pendekatan multi-rezim hukum dalam hukum pidana di Indonesia sebenarnya sudah tercantum dalam Kitab Udang Undang Hukum Pidana (KUHP) yang sering diistilahkan dengan Samenloop. Tindak pidana yang terjadi terkadang tidak hanya dilakukan satu orang yang melakukan beberapa peristiwa pidana (Samenloop van Strafbare Feiten) namun juga orang lain yang terlibat melakukan tindak pidana lain melalui tindak pidana asal (predicate crime), sehingga pendekatan multi-rezim hukum dalam hukum pidana di Indonesia perlu diatur lebih jelas sehingga semua tidak pidana yang terjadi dapat di tindak sesuai dengan peraturan yang berlaku. Putusan sanksi atau hukuman pada tindak pidana perikanan yang merupakan kejahatan ekonomi sering kali tidak cukup menimbulkan efek penjeraan dikarenakan putusan sanksi yang lebih ringan dibandingkan dengan kerusakan sumber daya alam yang diakibatkan oleh tindak pidana tersebut, sehingga dengan pendekatan multi-rezim hukum diharapkan dapat mencegah lolosnya pelaku pidana perikanan dan tindak pidana lain terkait perikanan dari proses hukum.

Perlu adanya evaluasi kewenangan pengadilan perikanan yang dalam pelaksanaan pendekatan multi-rezim hukum yang justru memberikan tantangan yang lebih besar. Perluasan kewenangan pengadilan perikanan atau pengembalian kewenangan mengadili perkara tindak pidana perikanan ke peradilan umum dapat menjadi solusi sehingga pelaksanaan pendekatan multi-rezim hukum menjadi lebih 
baik dan akan lebih memungkinkan bagi terlaksananya asas sederhana, cepat dan biaya ringan sebagaimana diamanatkan oleh Pasal 4 ayat (2) UU Pokok Pokok Kekuasaan Kehakiman.

\section{DAFTAR PUSTAKA}

Adji, Oemar Seno. Peradilan Bebas Negara Hukum. Erlangga, Jakarta: 1985. Albanese,

Jay S. Kejahatan Terorganisasi (Organized Crime) Akar dan Perkembangannya, Edisi Keenam, Kencana Prenadamedia Group, Jakarta, 2016.

Ali, Chaidir. Badan Hukum. Alumni Bandung: 2005

Ali, Mahrus. Kejahatan Korporasi: Kajian Relevasi Sanksi Tindakan Bagi Penanggulangan Kejahatan Korporasi. Arti Bumi Intaran Yogyakarta : 2008.

Amrullah, M. Arief. Kejahatan Korporasi. Bayumedia, Jawa Timur, 2006. Anwar, Yesmil. Sistem Peradilan Pidana, Widya Padjadjaran, Bandung, 2009. Atmasasmita, Romli. Sistem Peradilan Pidana (Perspektif Eksistensialisme dan Abolisionisme). Putra A. Bardin, Jakarta: 1996.

Azhary, Muhammad Tahir. Negara Hukum : Suatu Studi tentang Prinsip-prinsipnya Dilihat dari Segi Hukum Islam Implementasinya Pada Periode Negara Madinah Dan Masa Kini. Pernada Media Grup. Jakarta 2003.

Charles, Himawan. Hukum Maritim Indonesia. Fakultas Hukum Universitas Indonesia. Jakarta. 1981.

Dajamali, R. Abdul . Pengantar Hukum Indonesia. Cet. Kedelapan. Jakarta: Raja Grafindo Persada, Jakarta, 2003.

Djojodirdjo, M. Perbuatan melawan hukum. Pradnya Parami, Jakarta, 1979.

Fajar, M dan Achmad, Y. Dualisme penelitian hukum normatif \& empiris. Pustaka Pelajar, Yogyakarta, 2015.

Fauzi, Ahmad. Kebijakan Perikanan dan Kelautan. Jakarta: PT. Gramedia Pustaka Utama. 2005.

Gunawan Dj. Perlindungan Hukum Hak Penangkapan Ikan Nasional Tradisional Di Kabupaten Majenne, Makassar.Tahun 2005.

Harahap, Yahya M. Pembahasan Permasalahan dan Penerapan KUHP Edisi Kedua, Sinar Grafika Jakarta, 2000.

Hatrik, Hamzah. Asas Pertanggungjawaban Korporasi dalam Hukun Pidana (Strick Liability dan Vicarious Liability). Raja Grafindo, Jakarta, 1996.

Hatta, Moh. Beberapa Masalah Penegakan Hukum Pidana Umum Dan Pidana Khusus. Liberty Yogyakarta, Yogyakarta, 2009. 
Hartono, S. S. Penuntut dalam mempelajari hukum perdata Belanda. Bagian Umum, Dian Rakyat, Jakarta, 1992.

Huda, Ni'matul. Ilmu Negara, Rajawali Press, Depok. 2010.

Irving M. Copi. Intreduction to Logic dalam PM. Hadjon, Pengkajian Ilmu Hukum Dogmatik (Normatif), Yuridika , No.6 Tahun XI November-Desember, 1994.

Jonkers, J.E. Buku Pedoman Hukum Pidana Hindia Belanda, Bina Aksara, Jakarta, 1987.

Kansil, C.S.T. Pengantar Ilmu Hukum dan Tata Hukum Indonesia. Cet. Kedelapan. Jakarta: Balai Pustaka 1989.

Kanter E.Y dan Sianturi, S.R. Azas-Azas Hukum Pidana Indonesia dan Penerapannya, Alumni AHM-PTHM, Jakarta 1982.

Kurnia, Ida. Aspek Nasional dan Internasional Pemanfaatan Surplus Perikanan di Zona Ekonomi Eksklusif Indonesia, Sinar Grafika, Jakarta, 2000.

Kusnardi, Moh. Pengantar Hukum Tata Negara Indonesia. Cet. Ketujuh. Jakarta: 1988 Pusat Studi Hukum Tata Negara Fakultas Hukum Universitas Indonesia dan Sinar Bakti.

Kusnadi. Konflik Sosial Nelayan: Kemiskinan Perebutan Sumber Day Perikanan, LKiS Pelangi Aksara, Jakarta, 2002.

Kusumaatmadja, Mochtar. Pengantar Hukum Internasional, Alumni, Bandung, 2002.

Loqman, H. Loebby. Kapita Selekta Tindak Pidana di Bidang Perekonomian. Datacom, Jakarta: 2002. . HAM dalam HAP. Datacom Jakarta: 2002.

Leden Marpaung, Proses Penanganan Perkara Pidana Bagian Kedua, Sinar Grafika, Jakarta, 1995.

Lilik Mulyadi, Hukum Acara Pidana Normatif Teoritis, Praktik dan Permasalahannya, Alumni, Bandung, 2007.

M. Hadjon, Philipus. Merancang dan Menulis Penelitian Hukum Normatif (Teori dan Filsafat), Makalah, Tanpa Tahun.

Mahmudah, Nunung. Illegal Fishing Pertanggungjawaban Pidana Korporasi di Wilayah Perairan Indonesia, Sinar Grafika, Jakarta, 2015.

Marzuki, Peter Mahmud. Karakteristik Ilmu Hukum, Yuridika,-Jurnal Ilmu Hukum Fakultas Hukum Universitas Airlangga Surabaya, Volume 23, No. 2, Mei - Agustus 2008.

Marzuki, Peter Mahmud. Penelitian Hukum, Yuridika,- Jurnal Ilmu Hukum Fakultas Hukum Universitas Airlangga Surabaya, Volume 16, No. 2, 2002.

Marzuki, Peter Mahmud. Penelitian Hukum. Cet. Kelima. Kencana. Jakarta. 2009.

M. Friedman, Lawrence. American Law: An Introduction. Tata Nusa. Jakarta. 2001. 
Mertokusumo, Sudikno. Penemuan Hukum, Citra Aditya Bakti, Bandung, 2009.

Moeljatno. Azaz-Azaz Hukum Pidana. Cet. Keempat. Bina Aksara, Jakarta: 1987. . Asas-Asas Hukum Pidana, Edisi Revis. Rineka Cipta, Jakarta: 2008. . Kitab Undang-Undang Pidana. Cet. Kedua Puluh Satu. Jakarta: 2001 Bumi Aksara.

Mujahidin, Ahmad. Peradilan Satu Atap di Indonesia, Refika Aditama, Bandung, 2006.

Prasetyo, Teguh. Filsafat. Teori dan Ilmu Hukum, Raja Grafindo Persada, Jakarta, 2012.

Projodikoro, Wirjono. Tindak Tindak Pidana Tertentu di Indonesia. Refika Aditama, Bandung, 2006.

Raharjo, Satjipto. Ilmu Hukum. Citra Aditya Bakti, Bandung, 2000.

Samosir, D. Hukum acara perdata, tahaptahap penyelesaian perkara perdata. Edisi Pertama. CV Nuansa Aulia Bandung, 2011.

Soesilo, R. Kitab Undang-Undang Hukum Pidana, Politeia, Bogor, 1981.

Subekti. Implikasi Pengelolaan Sumberdaya Perikanan Laut di Indonesia Berlandaskan Code of Conduct for Responsible Fisheries (CCRF). Jurnal Ilmiah Hukum QISTI, Jakarta.

Suhardin, Y. \& Siahaan, R. H. Pengaruh budaya sistem hukum asing terhadap negara hukum kesejahteraan Indonesia. Sofmedia, Medan, 2015.

Suharto. Edi Membangun Masyarakat Memberdayakan Rakyat: Kajian Strategi Pembanguan Sosial dan Pekerjaan Sosial, Refika Aditama, Bandung, 2006.

Sukmaniar. Efektifitas Pemberdayaan Masyarakat dalam Pengelolaan Program Pengembangan Kecamatan (PPK) Pasca Tsunami di Kecamatan Lhoknga Kabupaten Aceh Besar, Tesis, Program Pascasarjana, Magister Teknik Pembangunan Wilayah Kota, Universitas Diponegoro, 2007.

Sulaiman, Faisal King. Politik Hukum Kekuasaan Kehakiman Indonesia, UII Press, Yogyakarta, 2017.

Theresia, Aprillia. Pembangunan Berbasis Masyarakat, Alvabeta, Jakarta, 2014. Tribawono, Djoko. Hukum Perikanan Indonesia Edisi Kedua (Revisi), Citra Aditya Bakti, Bandung, 2012.

Utrecht, E. Hukum Pidana II, Penerbitan Universitas, Bandung, 1962.

Wijoyo, Suparto. Bahan ajar : Hukum Perlindungan Lingkungan Hidup, Airlangga University Press, Surabaya, 2014.

Zaqiu Rahman. Perlindungan Dan Pemberdayaan Nelayan, Jurnal Rechtsvinding Online, Media Pembinaan Hukum Nasional, 25 Maret 2015.

Zein, Ahmad Yahya. Membangun Hukum Indonesia Kajian Filsafat, Teori hukum, Sosial, Pustaka Prisma, Yogyakarta, 2011. 
Zulfa, Achjani Eva. Perkembangan Sistem Pemidanaan dan Sistem Pemasyarakatan, Raja Grafindo Persada, Depok, 2011. 